\title{
Minimal Response of Multiple Myeloma
}

National Cancer Institute

\section{Source}

National Cancer Institute. Minimal Response of Multiple Myeloma. NCI Thesaurus. Code C111788.

Patients in whom some, but not all, the criteria for partial response are fulfilled are classified as minimal response (MR), provided the remaining criteria satisfy the requirements for minimal response. MR requires all of the following: 1. 25-49\% reduction in the level of the serum monoclonal paraprotein maintained for a minimum of 6 weeks; 2. 50-89\% reduction in 24 h urinary light chain excretion, which still exceeds $200 \mathrm{mg} / 24 \mathrm{~h}$, maintained for a minimum of 6 weeks; 3 . for patients with non-secretory myeloma only, 25-49\% reduction in plasma cells in a bone marrow aspirate and on trephine biopsy, if biopsy is performed, maintained for a minimum of 6 weeks; $4.25-49 \%$ reduction in the size of soft tissue plasmacytomas (by radiog raphy or clinical examination); 5. no increase in size or number of lytic bone lesions (development of a compression fracture does not exclude response) (adapted from National Comprehensive Cancer Network). 